\title{
Pengembangan LKM Berpandu Teori Pirie-Kieren Untuk Meningkatkan Kemampuan Pembuktian Matematis Teori Grup
}

\author{
Fauziah Hakim $^{* 1}$, Murtafiah ${ }^{2}$ \\ ${ }^{1,2}$ Universitas Sulawesi Barat;

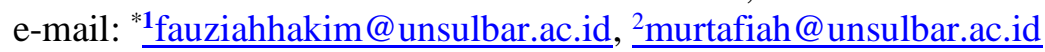

\begin{abstract}
Abstrak
Teori Grup merupakan materi dasar dari mata kuliah Struktur Aljabar yang sarat dengan definisi dan teorema. Oleh karena itu, mempelajari Teori Grup membutuhkan kemampuan penyelesaian pembuktian yang baik. Namun, kemampuan mahasiswa membuktikan masih sangat rendah. Kurangnya pembiasaan mahasiswa dalam menyelesaikan masalah pembuktian diduga sebagai penyebab lemahnya kemampuan mahasiswa dalam membuktikan. Dibutuhkan sebuah perangkat yang dapat digunakan untuk mampu melatih mahasiswa mengerjakan soal-soal pembuktian. Pada penelitian ini peneliti mengembangkan Lembar Kerja Mahasiswa (LKM) dengan berpandu teori pemahaman Pirie-Kieren. Teori Pirie-Kieren merupakan teori pemahaman yang terdiri dari delapan lapisan pemahaman, yakni primitive knowing, image making, image having, property noticing, formalising, observing, structuring, dan inventising. Penelitian ini merupakan penelitian pengembangan dengan pendekatan kuantitatif menggunakan model ADDIE (Analyze, Design, Development, Implementation, and Evaluation). Subjek uji coba penelitian ini adalah mahasiswa program study Pendidikan Matematika Universitas Sulawesi Barat yang mengambil mata kuliah Struktur Aljabar masa registrasi semester genap tahun akademik 2019 - 2020. Analisis data yang dilakukan menunjukkan bahwa LKM yang dikembangkan valid, efektif, dan praktis sehingga dapat digunakan untuk uji coba yang lebih luas. Selain itu diperoleh hasil bahwa kemampuan pembuktian matematis topik Teori Grup mahasiswa meningkat dan berada pada kategori sedang..
\end{abstract}

Kata kunci-Pengembangan, Teori Pirie-Kieren, Pembuktian, Teori Grup

\section{PENDAHULUAN}

Struktur aljabar secara umum dan teori grup secara khusus masih dikatakan salah satu topik yang sering dijadikan masalah bagi mahasiswa matematika di tingkat perguruan tinggi. Di banyak perguruan tinggi, struktur aljabar adalah mata kuliah awal bagi mahasiswa di mana mereka harus melampaui pembelajaran/pola perilaku tiruan yang sebelumnya mereka terapkan dalam memecahkan masalah matematika. Dalam mata kuliah ini, siswa harus memahami konsep-konsep abstrak, bekerja dengan prinsip-prinsip matematika yang penting, dan belajar menulis bukti. Meskipun tidak ada study formal, banyak mahasiswa melaporkan bahwa setelah mengikuti mata kuliah ini, mereka cenderung beralih dari matematika abstrak (Dubinsky, dkk, 1994).

Teori grup adalah topik penting di sebagian besar kurikulum matematika sarjana, dan membentuk dasar untuk study yang lebih tinggi baik di bidang matematika maupun di bidang lain di mana matematika diterapkan. Teori grup adalah salah satu topik pertama yang diajarkan dalam kurikulum sarjana matematika dan merupakan keterlibatan pertama mahasiswa ke dalam bidang aljabar abstrak khususnya, dan mungkin matematika perguruan tinggi pada umumnya. Materi teori grup sangat bagus untuk memperkenalkan beragam konsep yang penting untuk bahasa dan perangkat dari seluruh matematika. Ini berarti bahwa pengalaman dengan teori grup berpotensi sangat memperkaya ilmu matematika, tetapi juga menakutkan karena tidak terbiasa dengan pendekatan, bahasa, dan notasi yang digunakan (Naik, 2006). Konsep grup adalah gagasan paling penting untuk memasuki matematika sejak Newton dan Leibnitz menemukan kalkulus diferensial dan integral (Mackey, 2014). Teori grup sebagai bagian dari mata kuliah Struktur Aljabar memperkenalkan konsep tentang aljabar modern yang lebih ditekankan pada kemampuan berpikir logis dan bernalar sistematis dalam menyelesaikan masalah juga struktur aljabar sarat dengan definisi dan teorema sehingga mahasiswa dalam 
mempelajarinya dituntut kemampuan untuk membuktikan teorema dan dapat memanfaatkan definisi dan teorema-teorema yang ada dalam menyelesaikan soal-soal yang pada umumnya berbentuk pembuktian (Hakim, 2019).

Permasalahannya, kemampuan membuktikan mahasiswa khususnya pada topik teori grup masih sangat rendah. Data skor ujian akhir semester (UAS) mata kuliah Struktur Aljabar dengan topik Teori Grup yang diperoleh dari mahasiswa Program Study Pendidikan Matematika Universitas Sulawesi Barat yang mengambil mata kuliah Struktur Aljabar masa registrasi semester genap tahun akademik 2018 - 2019 menunjukkan bahwa dari 72 mahasiswa yang mengikuti UAS dengan topik Teori Grup, hanya 5 mahasiswa yang memperoleh skor di atas 70 .

Hal ini disebabkan karena mahasiswa kurang terbiasa mengerjakan soal-soal pembuktian, mahasiswa perlu dilatih untuk mampu mengerjakan soal-soal tersebut. Jika materi pembuktian hanya diberikan langsung dengan cara menjelaskan langkah-langkah pembuktian, maka mahasiswa tidak terlibat didalam proses pembuktian tersebut. Aktivitas mereka hanya mencatat dan cenderung menghafalnya saja (Pasandaran, dkk, 2017). Selain itu, penyebab lain adalah bahan ajar struktur aljabar yang ada juga bersifat abstrak, sehingga mahasiswa kurang termotivasi dalam membaca buku-buku penunjang yang mengakibatkan aktivitas mahasiswa sangatlah rendah (Yunita \& Septia, 2014). Oleh karena itu, setiap aktivitas pembelajaran harus diatur sebaik mungkin agar mahasiswa dapat membangun pengetahuan secara mandiri. Untuk mewujudkan hak tersebut maka perlu dikembangkan sebuah perangkat pembelajaran dalam bentuk lembar kerja mahasiswa (LKM). Lembar kerja mahasiswa (LKM) adalah suatu bahan ajar cetak yang berupa lembar-lembaran kertas yang berisi materi, ringkasan, dan petunjuk pelaksanaan tugas pembelajaran yang harus dikerjakan oleh mahasiswa, baik bersifat teoritis dan/atau praktis yang mengacu pada kompetensi yang harus dicapai mahasiswa, dan penggunaannya tergantung dengan bahan ajar lain (Prastowo, 2013).

Penyelesaian masalah pembuktian, sangat erat kaitannya dengan seberapa jauh pemahaman mahasiswa terhadap soal yang ditemui. Salah satu teori pemahaman yang terkait dengan hal tersebut adalah teori yang dikemukakan oleh Pirie dan Kieren. Pirie dan Kieren (1994) memandang pemahaman sebagai sebuah proses pertumbuhan yang utuh, dinamis, berlapis tetapi tidak linear, dan tidak pernah berakhir. Mereka menolak konsep pertumbuhan pemahaman sebagai sebuah fungsi yang naik secara monoton. Mereka mengemukakan model pemahaman berupa delapan level atau lapisan pemahaman, yaitu: primitive knowing, image making, image having, property noticing, formalising, observing, structuring, dan inventising. Inti dari teori ini adalah "memahami" tidak selalu merupakan pertumbuhan yang linear dan kontinu. Seseorang sering kembali ke level pemahaman sebelumnya (lapisan yang lebih dalam) untuk maju ke level pemahaman selanjutnya (lapisan yang lebih luar). Gambar 1 menunjukkan delapan lapisan pemahaman menurut PirieKieren.

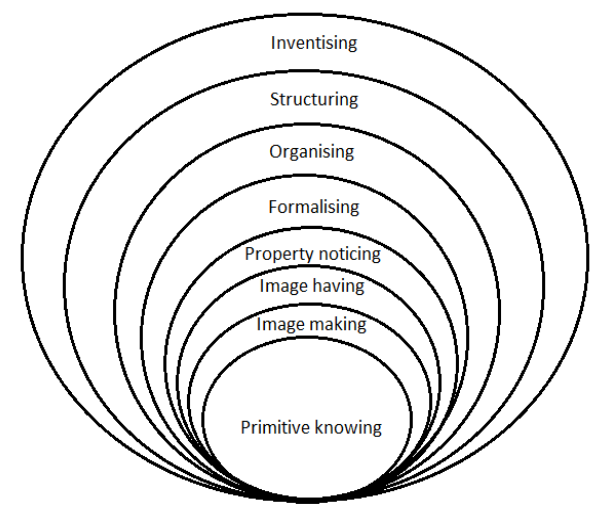

\section{Gambar 1 Lapisan Pemahaman Menurut Teori Pirie-Kieren}

Setiap level atau lapisan pemahaman berdasarkan teori Pirie-Kieren jika dikaitkan dengan masalah pembuktian matematis dapat memiliki indikator sebagaimana pada Tabel 1.

Tabel 1 Indikator Lapisan Pemahaman Berdasarkan Teori Pirie-Kieren Jika Dikaitkan dengan Masalah Pembuktian Matematis 
https://jurnal.unsulbar.ac.id/index.php/saintifik

\begin{tabular}{|c|c|c|}
\hline No & Pemahaman & Indikator \\
\hline 1 & Primitive knowing & $\begin{array}{l}\text { - Memahami semua definisi dari istilah-istilah yang ditemukan } \\
\text { dalam masalah. }\end{array}$ \\
\hline 2 & Image making & $\begin{array}{l}\text { - Mendapatkan ide atau gambaran yang akan digunakan dalam } \\
\text { penyelesaian masalah. } \\
\text { - Menjelaskan ide atau gambaran penyelesaian melalui contoh- } \\
\text { contoh. }\end{array}$ \\
\hline 3 & Image having & $\begin{array}{l}\text { - Mendapatkan ide atau gambaran yang akan digunakan dalam } \\
\text { penyelesaian masalah. } \\
\text { - Menjelaskan ide atau gambaran penyelesaian tanpa contoh. }\end{array}$ \\
\hline 4 & Property noticing & $\begin{array}{l}\text { - Menyadari adanya hubungan antar definisi-definisi yang } \\
\text { dipahami pada tahap primitive knowing. } \\
\text { - Memverifikasi hubungan antar definisi-definisi tersebut. }\end{array}$ \\
\hline 5 & Formalising & $\begin{array}{l}\text { - Membuat suatu konsep terkait hubungan definisi-definisi } \\
\text { tersebut. }\end{array}$ \\
\hline 6 & Organising & $\begin{array}{l}\text { - Menggunakan konsep yang ditemukan untuk menyelesaikan } \\
\text { masalah yang diberikan. } \\
\text { - Menemukan pola terstruktur dari konsep untuk menyelesaikan } \\
\text { masalah yang diberikan. } \\
\text { - Membuat suatu pernyataan formal dari pola yang ditemukan } \\
\text { untuk menyelesaikan masalah yang diberikan. }\end{array}$ \\
\hline 7 & Structuring & $\begin{array}{l}\text { - Mengaitkan hubungan antara teorema yang satu dengan } \\
\text { teorema yang lain dan mampu membuktikannya berdasarkan } \\
\text { argumen logis. }\end{array}$ \\
\hline 8 & Inventising & $\begin{array}{l}\text { - Memiliki sebuah pemahaman terstruktur komplit dan } \\
\text { menciptakan pertanyaan-pertanyaan baru yang dapat tumbuh } \\
\text { sebagai sebuah konsep yang baru. }\end{array}$ \\
\hline
\end{tabular}

(Hakim, 2019)

Kedelapan lapisan tersebut selanjutnya akan diintegrasikan ke dalam lembar kerja mahasiswa (LKM). Berdasarkan keunggulan-keunggulan tersebut, maka dianggap penting untuk melakukan penelitian pengembangan lembar kerja mahasiswa berpandu teori Pirie-Kieren untuk meningkatkan kemampuan pembuktian matematis teori grup.

\section{METODE PENELITIAN}

\subsection{Desain Penelitian}

Penelitian ini bertujuan mengembangkan lembar kerja mahasiswa (LKM) berpanduan teori PirieKieren untuk meningkatkan kemampuan pembuktian matematis mahasiswa khususnya pada topik teori grup mata kuliah Struktur Aljabar. Berdasarkan tujuan penelitian tersebut, model pengembangan yang digunakan adalah model ADDIE (Analyze, Design, Development, Implementation, and Evaluation) yang mengacu pada Lee \& Owens (2004). Diagram alur pengembangan yang digunakan dapat dilihat pada Gambar 2. 


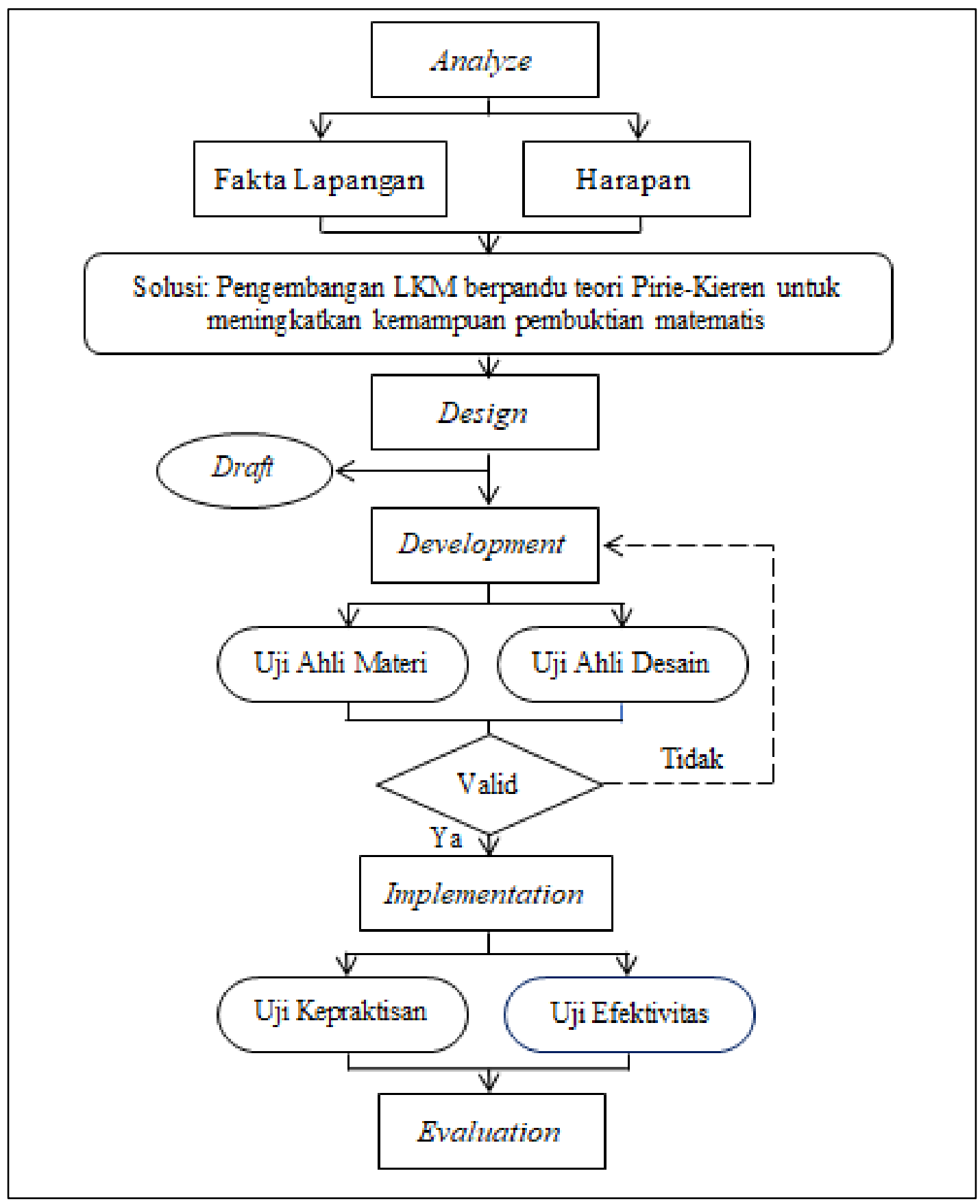

Gambar 2 Diagram Alur Penelitian

\subsection{Subjek Penelitian}

Subjek penelitian ini adalah mahasiswa Program Study Pendidikan Matematika Universitas Sulawesi Barat yang memprogramkan mata kuliah Struktur Aljabar pada tahun akademik 2019/2020.

\subsection{Instrumen Penelitian dan Teknik Pengumpulan Data}

Instrumen penelitian yang digunakan adalah instrumen untuk mengukur validitas, efektivitas, dan kepraktisan lembar kerja mahasiswa (LKM) yang dikembangkan. Instrumen penilaian validitas LKM yang dikembangkan menggunakan lembar penilaian atau lembar validation yang diberikan kepada dua orang 
https://jurnal.unsulbar.ac.id/index.php/saintifik

validator profesional dalam bidang teori grup. Instrumen penilaian efektivitas LKM yang digunakan adalah tes pembuktian matematis dengan topik teori grup khususnya materi aksioma dasar grup. Adapun instrumen yang digunakan untuk menilai kepraktisan adalah angket respons mahasiswa.

\subsection{Teknik Analisis Data}

\subsubsection{Analisis Validitas LKM}

Data hasil validitas LKM yang telah dikembangkan dianalisis secara deskriptif kuantitatif dan deskriptif kualitatif. Hasil analisis skor oleh dua orang validator di rata-rata pada tiap aspek dan dikonversi menggunakan kategori pada Tabel 2.

Tabel 2 Kategori Penilaian Validasi LKM

\begin{tabular}{|c|c|l|}
\hline Interval Skor & Kategori & \multicolumn{1}{|c|}{ Keterangan } \\
\hline $3,60 \leq$ skor $\leq 4,00$ & Valid & Dapat digunakan tanpa revisi \\
\hline $2,60 \leq$ skor $\leq 3,59$ & Cukup valid & Dapat digunakan dengan sedikit revisi \\
\hline $1,60 \leq$ skor $\leq 2,59$ & Kurang valid & Dapat digunakan dengan banyak revisi \\
\hline $1,00 \leq$ skor $\leq 1,59$ & Tidak valid & Belum dapat digunakan dan masih memerlukan konsultasi \\
\hline
\end{tabular}

(Ratumanan \& Laurens, 2015)

Setiap aspek yang divalidasi wajib mencapai skor rata-rata minimal 2,60 agar dapat dikatakan valid dan dapat digunakan dalam kegiatan pembelajaran.

\subsubsection{Analisis Efektivitas LKM}

Efektivitas LKM yang telah dikembangkan diukur melalui tes pembuktian matematis dengan topik teori grup khususnya materi aksioma dasar grup. Tes dibuat berdasarkan level pemahaman menurut PirieKieren dengan memperhatikan indikator-indikator setiap levelnya. Penelitian ini menggunakan desain one group pre-test dan post-test. Sebelum penggunaan lembar kerja mahasiswa yang dikembangkan, peneliti memberikan pretest. Penerapan LKM dilakukan pada topik teori grup khususnya aksioma dasar grup. Setelah LKM diterapkan, mahasiswa mengerjakan posttest.

Kemampuan pembuktian matematis mahasiswa dianalisis menggunakan perbedaan skor sebelum dan setelah penerapan LKM berpandu teori Pirie-Kieren yang telah dikembangkan. Skor N-Gain dianalisis menggunakan rumus (1) berikut.

$$
N-\text { Gain score }=\frac{\text { posttest score-pretest score }}{\text { maximum score-pretest score }}
$$

Adapun kriteria perolehan skor N-Gain yang digunakan sesuai pada Tabel 3.

Tabel 3 Kategori Perolehan Skor N-Gain

\begin{tabular}{|c|c|}
\hline Skor N-Gain & Kategori \\
\hline$g \geq 0,7$ & Tinggi \\
\hline $0,3 \leq g<0,7$ & Sedang \\
\hline$g<0,3$ & Rendah \\
\hline
\end{tabular}

Jika skor N-Gain $\geq 0,3$, maka LKM yang dikembangkan dikatakan dapat meningkatkan kemampuan pembuktian matematis mahasiswa.

\subsubsection{Analisis Kepraktisan LKM}


https://jurnal.unsulbar.ac.id/index.php/saintifik

Angket respons mahasiswa digunakan untuk mengukur kepraktisan LKM. Data respons mahasiswa dianalisis deskriptif kuantitatif dalam bentuk persentase. Hasil persentase lalu dikategorikan sesuai Tabel 4.

Tabel 4 Kategori Persentase Respons Mahasiswa

\begin{tabular}{|c|c|}
\hline Persentase Skor & Kategori \\
\hline $76 \%-100 \%$ & Positif \\
\hline $51 \%-75 \%$ & Cukup positif \\
\hline $26 \%-50 \%$ & Kurang positif \\
\hline $0 \%-25 \%$ & Tidak positif \\
\hline
\end{tabular}

(Riduwan, 2014)

\section{HASIL DAN PEMBAHASAN}

\subsection{Hasil Penelitian}

Hasil penelitian ini terdiri dari validitas, keefektifan, dan kepraktisan Lembar Kerja Mahasiswa (LKM) yang dikembangkan untuk meningkatkan kemampuan pembuktian matematis teori grup mahasiswa dengan penjelasan sebagai berikut.

\subsubsection{Analisis Data Validitas LKM}

Penilaian dua orang validator terhadap Lembar Kerja Mahasiswa (LKM) berpandu teori Pirie-Kieren yang dikembangkan meliputi tiga aspek yaitu format, isi, dan bahasa. Hasil penilaian kedua validator tersebut disajikan dalam Tabel 5.

Tabel 5 Hasil Uji Validasi Lembar Kerja Mahasiswa (LKM)

\begin{tabular}{|c|c|c|}
\hline Aspek Penilaian & Rata-rata & Kategori \\
\hline Format & 3,67 & Valid \\
\hline Isi & 3,50 & Cukup Valid \\
\hline Bahasa & 3,75 & Valid \\
\hline Rata-rata & 3,64 & Valid \\
\hline
\end{tabular}

Berdasarkan data pada Tabel 5, semua aspek penilaian memperoleh skor rata-rata di atas 2,60, sehingga ketiga aspek pada Lembar Kerja Mahasiswa termasuk dalam kategori valid dan dapat digunakan dalam proses pembelajaran.

\subsubsection{Analisis Data Efektivitas LKM}

Efektivitas Lembar Kerja Mahasiswa (LKM) berpandu teori Pirie-Kieren diukur melalui skor pretest, posttest, dan $N$-gain setelah LKM digunakan. Skor pretest, posttest, dan $N$-gain pada uji coba terbatas dapat dilihat pada Tabel 6.

Tabel 6 Hasil Uji Coba Terbatas Lembar Kerja Mahasiswa (LKM)

\begin{tabular}{|c|c|c|c|c|}
\hline No & Skor Pretest & Skor Posttest & $N$-gain & Kategori \\
\hline 1 & 65 & 83 & 0,51 & Sedang \\
\hline 2 & 15 & 50 & 0,41 & Sedang \\
\hline 3 & 15 & 78 & 0,74 & Tinggi \\
\hline 4 & 30 & 70 & 0,57 & Sedang \\
\hline 5 & 15 & 30 & 0,18 & Rendah \\
\hline 6 & 25 & 79 & 0,72 & Tinggi \\
\hline 7 & 45 & 88 & 0,78 & Tinggi \\
\hline
\end{tabular}


https://jurnal.unsulbar.ac.id/index.php/saintifik

\begin{tabular}{|c|c|c|c|c|}
\hline No & Skor Pretest & Skor Posttest & $N$-gain & Kategori \\
\hline 8 & 15 & 67 & 0,61 & Sedang \\
\hline 9 & 15 & 65 & 0,59 & Sedang \\
\hline 10 & 40 & 70 & 0,50 & Sedang \\
\hline 11 & 20 & 80 & 0,75 & Tinggi \\
\hline 12 & 30 & 75 & 0,64 & Sedang \\
\hline 13 & 25 & 72 & 0,63 & Sedang \\
\hline 14 & 20 & 78 & 0,73 & Tinggi \\
\hline 15 & 15 & 63 & 0,56 & Sedang \\
\hline Jumlah & 390 & 1048 & & \\
\hline Rata-rata & 26 & 70 & 0,59 & Sedang \\
\hline
\end{tabular}

Tabel 6 menunjukkan bahwa skor $N$-gain kemampuan pembuktian matematis mahasiswa dalam menyelesaikan masalah teori grup berada pada kategori rendah sebanyak 1 mahasiswa, berada pada kategori sedang sebanyak 9 mahasiswa, dan berada pada kategori tinggi sebanyak 5 mahasiswa. Hal ini menunjukkan bahwa terjadi peningkatan kemampuan pembuktian matematis mahasiswa setelah digunakan Lembar Kerja Mahasiswa (LKM) berpandu teori Pirie-Kieren.

\subsubsection{Analisis Data Kepraktisan LKM}

Kepraktisan Lembar Kerja Mahasiswa (LKM) diukur melalui angket respons mahasiswa terhadap kegiatan pembelajaran dengan menggunakan LKM berpandu teori Pirie-Kieren yang dikembangkan. Hasil analisis respons mahasiswa pada uji coba terbatas disajikan pada Tabel 7.

Tabel 7 Hasil Uji Kepraktisan Lembar Kerja Mahasiswa (LKM)

\begin{tabular}{|c|l|c|c|c|c|}
\hline No & \multicolumn{1}{|c|}{ Aspek } & Skor Total & Skor Maksimal & Persentase & Kategori \\
\hline 1 & Petunjuk dan desain & 322 & 375 & $86 \%$ & Positif \\
\hline 2 & $\begin{array}{l}\text { Kesesuaian dengan tujuan } \\
\text { pembelajaran }\end{array}$ & 316 & 375 & $84 \%$ & Positif \\
\hline 3 & Bahasa & 171 & 225 & $76 \%$ & Positif \\
\hline 4 & Waktu & 51 & 75 & $68 \%$ & Cukup positif \\
\hline \multicolumn{4}{|r|}{ Rata-rata } & $79 \%$ & Positif \\
\hline
\end{tabular}

\subsection{Pembahasan}

Pada bagian ini dikemukakan pembahasan mengenai hasil penelitian berupa ketercapaian tujuan penelitian. Ketercapaian ini dikaitkan dengan kriteria validitas, efektivitas, dan kepraktisan Lembar Kerja Mahasiswa (LKM) yang dikembangkan.

\subsubsection{Validitas}

Berdasarkan hasil penelitian yang dikemukakan sebelumnya terkait validitas, diperoleh data bahwa dari 3 aspek yang divalidasi oleh dua orang validator, yakni aspek format, isi, dan bahasa, ketiga aspek tersebut dapat dikategorikan valid dan dapat digunakan meskipun untuk format isi harus dilakukan revisi kecil terlebih dahulu. Untuk aspek format berisikan indikator petunjuk yang ditampilkan, tata letak warna, dan desain, serta kolom yang disediakan untuk jawaban mahasiswa pada LKM. Aspek isi mengukur langkah-langkah pembuktian yang disediakan, kesinambungan antar langkah-langkah, dan keruntututan langkah-langkah tersebut. Adapun untuk aspek bahasa mengukur apakah bahasa yang digunakan dalam LKM komunikatif, interakif, dan mampu merangsang kemampuan pembuktian matematis mahasiswa, kelugasan bahasa, sejauh mana bahasa yang digunakan dapat dipahami serta tidak multi tafsirnya bahasa yang digunakan. 
https://jurnal.unsulbar.ac.id/index.php/saintifik

\subsubsection{Efektivitas}

Dari skor pretest, posttest, dan $\mathrm{N}$-gain yang telah dipaparkan pada bagian sebelumnya menunjukkan bahwa LKM efektif dalam meningkatkan skor kemampuan pembuktian matematis mahasiswa pada topik Teori Grup. Bahkan rata-rata skor $N$-gain dari 15 mahasiswa yang berpartisipasi dalam uji coba terbatas berada pada kategori sedang. Begitupun ketika dilihat dari rata-rata skor pretest yang hanya 26 dan meningkat menjadi 70 setelah penggunaan LKM yang dikembangkan.

\subsubsection{Kepraktisan}

Respons mahasiswa terhadap LKM yang dikembangkan menunjukkan bahwa LKM yang dikembangkan memunculkan respons positif dari mahasiswa. Aspek petunjuk dan desain, kesesuaian dengan tujuan pembelajaran, dan bahasa berada pada kategori positif. Adapun aspek waktu berada pada kategori positif. Hal ini karena dalam mengerjakan soal pembuktian memang membutuhkan waktu yang tidak singkat.

\section{KESIMPULAN}

Berdasarkan pembahasan pada bagian sebelumnya, maka penelitian ini menghasilkan kesimpulan bahwa LKM yang dikembangkan untuk meningkatkan kemampuan pembuktian matematis topik Teori Grup mahasiswa dinyatakan valid, efektif, dan praktis. Kemampuan pembuktian matematis topik Teori Grup mahasiswa meningkat dan berada pada kategori sedang.

\section{DAFTAR PUSTAKA}

Dubinsky, E., Dautermann , J., Leron, U. dan Zazkis, R., 1994, On learning fundamental concepts of group theory, Educational Studies in Mathematics, DOI: 10.1007/BF01273732

Hake, R,R., 1999, Annalyzing Change/Gain Scores, AREA-D American Education Research Association's Devision.D, Measurement and Research Methodology.

Hakim, F., 2019, Analisis pemahaman mahasiswa PPs UNM berpandu teori Pirie-Kieren dalam menyelesaikan masalah pembuktian pada Teori Grup ditinjau dari gaya kognitif dan adversity quotient, Pedamath Journal On Pedagogical Mathematics, No. 2, Vol.1, 86-101.

Mackey, G.W., 1973, Group theory and its significance for mathematics and physics, Proceedings of the American Philosophical Society, No. 5, Vol. 117, 374-380.

Naik, V., 2006, Group theory: a first journey, Chennai Mathematical Institute.

Pasandaran, R.F., Kartika, D.M.R. dan Masni, E.D., 2017, Pengembangan lembar kerja mahasiswa (LKM) pada pembuktian dalil-dalil teori segitiga, Prosiding Seminar Nasional ISSN 2443-1109, No. 1, Vol.3, 147-153.

Pirie, S. dan Kieren, T., 1994, Growth in mathematical understanding: how we can characterize it and how we can represent it. Educational Studies in Mathematics, 9, 160-190.

Prastowo, A, 2013. Panduan Kreatif Membuat Bahan Ajar Inovatif. Yogyakarta: Diva Press.

Ratumanan, T. G. dan Laurens, T., 2015, Penilaian Hasil Belajar pada Tingkat Satuan Pendidikan Edisi 3. Yogyakarta: Pensil Komunika.

Riduwan, 2014, Metode \& Teknik Penyusunan Proposal Penelitian, Bandung: Alfabeta.

Yunita, A. dan Septia, T, 2014, Efektivitas lembar kerja mahasiswa (LKM) terbimbing dalam perkuliahan struktur aljabar, Jurnal Pelangi, No. 2, Vol. 6, 101-111. 